\title{
Nursery Service in Modern Days
}

\author{
Da Yong Lu*1, Yu Zheng Chen², Da Feng Lü and Jin Yu Che ${ }^{1}$ \\ ${ }^{1}$ Shanghai University, China \\ ${ }^{2}$ The Second Hospital of Neijiang District, Sichuan Province, China
}

*Corresponding author: Da Yong Lu, Shanghai University, Shanghai200333, China.

Received Date: April 15, 2019

Published Date: April 26, 2019

\begin{abstract}
Nursery service is the main part of healthcare efforts worldwide. Patient's recovery and survivals need high quality nursery to support and promotions. In this editorial, many pathways, like education improvements, medical knowledge for nurses and willing to take parts of more responsibility from nursery care are addressed.
\end{abstract}

Keywords: Healthcare; Nursing; Medical service; Modern technology; Mathematicians; Psycho-analysis

\section{Introduction for Nursery Service Worldwide}

Today, a half of major diseases are chronic diseases. Their recovery processes are not defined in operation-room (surgery). But, getting better in the bedside (therapeutic conventionsdrugs, nutrition, instruments and nursery). A great proportion of healthcare services are both doctors and nursing [1-7]. Any unilateral activity may compromise medication quality. The promotion of the quality and scope of nursing activity is especially important for medical study and practices. However, current nursing activities in hospitals does not receive enough academic respects globally.

\section{Requirement for High Quality Nursery}

There is no nursery knowledge that can be applied on every medical discipline. Nursery education plays key role for clinical nursery practice $[8,9]$.

System developments for nursery services and education are indispensable [10]. This educational difference requires efforts among teachers and nurses. Good teamwork and cooperative efforts can provide better nursery services [11-13]. Therapeutics in the future is no longer a performance and decision-making by doctors alone. Many technical or assistance forces will take part of medical practice for quality boosting-including pharmacologists, pathologists, biochemical technologists, nurses, mathematicians and many others [11-13]. Without the assistance of these experts, clinical doctors will be narrow-minded and difficult to execute best therapeutics for all patients.

\section{Medical Services in Different Areas}

In summary, different types of nursery play key roles in clinical trials, especially chronic diseases, such as HIV/AIDS treatments [14], mental diseases [15-18], bone disorders [18-21], metabolic diseases [22-27], cancers [28,29] and so on. To promote medical practice, nurses must play very important responsibility in medical treatments.

\section{Feedback from Nurses}

If a doctor makes mistake in patient's treatment, nurses must report these mistakes to regulatory organization [30]. These efforts can determine the quality of healthcare services in the hospitals.

\section{Conclusion}

Patient's care and nursery play important roles for patient treatments and recovery. High quality nursery work is much needed.

\section{Acknowledgment}

None.

\section{Conflict of Interest}

No conflict of interest.

\section{References}

1. (2013) An Old Disease, A New Insights. In: Shamm Ahmad [Ed.], Springer Science, USA. 
2. Zimmet PZ, Magliano DJ, Herman WH, Shaw JE (2014) Diabetes; a 21st century challenge. Lancet Diabetes Endocrinol 2(1): 56-64.

3. Grimaccia F, Kanavos P (2014) Cost, outcome, treatment pathways and challenges for diabetes care in Italy. Globalization and Health 10(1): 58.

4. Lu DY, Che JY, Yarla NS, Putta S, Shen Y (2018) Bone disease recovery strategies, An overview. EC Orthopaedics 10(1): 1-3.

5. Lu DY (2014) Personalized cancer chemotherapy, an effective way for enhancing outcomes in clinics ( $1^{\text {st }}$ edn.), Woodhead Publishing, Elsevier, UK, pp. 1-84.

6. Lu DY (2017) Suicide Risks and Treatments, New Ideas and Future Perspectives. In: Da-Yong Lu [Ed.], Nova Science Publishers, New York, USA.

7. Lu DY (2017) HIV/AIDS Treatments, Fight for a Cure. In: Da-Yong Lu [Ed.], LAMBERT Academic Publishing, Germany, Europe.

8. Lu DY, Chen YZ, Lu DF, Che JY (2018) Patient's care and nursery in different diseases. Hospice \& Palliative Medicine International Journal 3(1): 28-30.

9. Lu DY, Chen YZ, Lu DF, Che JY (2018) Patient's care and nursery in modern medicine. Nursery Practice and Health Care 1(1): 101.

10. Ghaffari M (2019) Building a community of learners: Lessons learned. Nursery Practice and Health Care 1(1): 104.

11. Lu DY, Zhu PP, Lu TR, Che JY (2016) The suicidal risks and treatments, seek medications from multi-disciplinary. Cent Nerv Syst Agents Med Chem 16(3): 231-239.

12. Lu DY, Zhu PP, Wu HY, Lu Y, Che JY (2017) New modes of suicide/mental disorder diagnostics and Therapeutics. In: Da-Yong Lu [Ed.], Suicide Risks and Treatments, New Ideas and Future Perspectives, Nova Science Publishers, New York, USA, pp. 51-62.

13. Lu DY, Wu HY, Yarla NS, Xu B, Ding J, et al. (2018) HAART in HIV/AIDS treatments, future trends. Infect Disord Drug Targets 18(1): 15-22.

14. Serafini G, Salano P, Amore M (2015) Suicidal ideation: a comprehensive overview. Suicidal Ideation: Predictors, Prevalence and Prevention. In: Bradley Weaver [Ed.], Nova Science Publishing, USA, pp. 1-42.

15. While D, Bickley H, Roscoe A, Windfuhr K, Rahman S, et al. (2012) Implementation of mental health service recommendations in England and Wales and suicide rates, 1997-2006: a cross-sectional and beforeand-after observational study. Lancet 379(9820): 1005-1012.
16. Lu DY, Lu TR, Lu Y, Cao S (2017) Introduction for suicide study. J Metabolic Synd 6(2): 227.

17. Lu DY, Zhu PP, Wu HY, Yarla NS, Xu B, et al. (2018) Human suicide risk and treatment study. Cent Nerv Syst Agents Med Chem 18(3): 206-212.

18. Melton J (1993) Hip fracture; a worldwide problem today and tomorrow. Bone 14(1): S1-8.

19. Silva DMW (2018) Diagnosis of osteoporosis; bone mineral density, risk factors, or both. EC Orthopaedics 9(7): 500-502.

20. Lu DY, Che JY, Shen Y (2019) Osteoporosis in old women, therapeutic selection. EC Orthopaedics 9(7): 386.

21. Lu DY, Che JY, Shen Y (2018) Clinical treatments of osteoporosis, how to target co-morbidities. EC Orthopaedics (11): 781-782.

22. Putta S, Peluso I, Yarla NS, Kilari EK, Bishayee A, et al. (2017) Diabetes mellitus and male aging, pharmacotherapeutics and clinical implications. Curr Pharm Des 23(30): 4475-4483.

23. Lu DY, Che JY, Yarla NS, Zhu H, Lu TR, et al. (2018) Type 2 diabetes study, introduction and perspective. The Open Diabetes Journal 8: 13-21.

24. Lu DY, Che JY, Yarla NS, Wu HY, Lu TR, et al. (2018) Type 2 diabetes treatment and drug development study. The Open Diabetes Journal 8: 22-33.

25. Lu DY, Che JY, Lu Y, Yarla NS, Xu B, et al. (2018) An overview of obesity. Metabolomics 8(2): 200.

26. Lu DY, Che JY, Wu HY, Yarla NS, Xu B, et al. (2018) Obesity, risks and managements. Metabolomics 8(1): e156

27. Lu DY, Che JY, Lu TR, Lu Y, Huang YK, et al. (2018) Pathology and treatments of obesity. Trends in Medicine 8 (5): 157.

28. Lu DY, Lu TR, Xu B, Ding J, Lu Yi, et al. (2017) Perspectives of personalized cancer therapy. Adv Biotechnology \& Microbiology 4 (3): 555637.

29. Lu DY, Lu TR, Che JY, Shen Y, Yarla NS (2018) Individualized cancer therapy, future approaches. Current Pharmacogenomics \& Personalized Medicine 16(2): 156-163.

30. Dirik HF, Samur M, Intepeler SS, Hewison A (2019) Nurses' identification and reporting of medication errors. J Clin Nurs 28(5-6): 931-938. 